\title{
OPEN The impact of rising sea temperatures on an Arctic top predator, the narwhal
}

\author{
P. Chambault ${ }^{1 凶}$, O. M. Tervo ${ }^{1}$, E. Garde ${ }^{1}$, R. G. Hansen ${ }^{1}$, S. B. Blackwell $\mathbb{1}^{2}$, T. M. Williams ${ }^{3}$, \\ R. Dietz ${ }^{4}$, C. M. Albertsen $\mathbb{1}^{5}$, K. L. Laidre ${ }^{6}$, N. H. Nielsen ${ }^{7}$, P. Richard ${ }^{8}$, M. H. S. Sinding ${ }^{1,9}$, \\ H. C. Schmidt ${ }^{1} \&$ M. P. Heide-Jørgensen ${ }^{1}$
}

Arctic top predators are expected to be impacted by increasing temperatures associated with climate change, but the relationship between increasing sea temperatures and population dynamics of Arctic cetaceans remains largely unexplored. Narwhals (Monodon monoceros) are considered to be among the most sensitive of Arctic endemic marine mammals to climate change due to their limited prey selection, strict migratory patterns and high site fidelity. In the context of climate change, we assume that the population dynamics of narwhals are partly influenced by changes in environmental conditions, with warm areas of increasing sea temperatures having lower abundance of narwhals. Using a unique large dataset of 144 satellite tracked narwhals, sea surface temperature (SST) data spanning 25 years (1993-2018) and narwhal abundance estimates from 17 localities, we (1) assessed the thermal exposure of this species, (2) investigated the SST trends at the summer foraging grounds, and (3) assessed the relationship between SST and abundance of narwhals. We showed a sharp SST increase in Northwest, Mideast and Southeast Greenland, whereas no change could be detected in the Canadian Arctic Archipelago (CAA) and in the Greenland Sea. The rising sea temperatures were correlated with the smallest narwhal abundance observed in the Mideast and Southeast Greenland ( $<2000$ individuals), where the mean summer sea temperatures were the highest $\left(6.3^{\circ} \mathrm{C}\right)$ compared to the cold waters of the $\mathrm{CAA}\left(0.7^{\circ} \mathrm{C}\right)$ that were associated with the largest narwhal populations (>40,000 individuals). These results support the hypothesis that warming ocean waters will restrict the habitat range of the narwhal, further suggesting that narwhals from Mideast and Southeast Greenland may be under pressure to abandon their traditional habitats due to ocean warming, and consequently either migrate further North or locally go extinct.

Climate change is affecting almost all regions and ecosystems, with the Arctic demonstrating the greatest, irreversible consequences on marine life. Rapid sea-ice loss and increasing temperatures ${ }^{1,2}$ are altering the distribution and abundance of low trophic-level organisms, generating cascading effects through the entire food chain from phytoplankton to mammalian predators ${ }^{3}$. Arctic marine mammals have the potential to move over long distances to adapt to changing and erratic resource availability. However, their capacity to adjust long-term adaptations, like site-fidelity and fixed migratory patterns, to climate-induced perturbations remains poorly known ${ }^{4,5}$.

Among Arctic cetaceans, the narwhal (Monodon monoceros) has a large geographic range extending from the Canadian Arctic Archipelago (CAA) to East Greenland, Svalbard and the western part of the Russian Arctic ${ }^{6-11}$. Narwhals are known to exhibit a high degree of site-fidelity and to be closely associated with specific migratory corridors during spring and fall movements between summer and winter grounds ${ }^{12}$. During winter, narwhals are mainly found in offshore areas over deep water and often in areas completely covered with pack-ice with only leads available for breathing. In spring the narwhals move towards coastal areas. The inshore summer foraging grounds, where they congregate during the open water season, are considered the primary basis for identifying separate population units of narwhals ${ }^{13}$.

\footnotetext{
${ }^{1}$ Greenland Institute of Natural Resources, Strandgade 91, 1401 Copenhagen, Denmark. ${ }^{2}$ Greeneridge Sciences, Inc, 5266 Hollister Avenue, Suite 107, Santa Barbara, CA 93111, USA. ${ }^{3}$ University of California, Santa Cruz, USA. ${ }^{4}$ Department of Bioscience, Aarhus University, Frederiksborgvej 399, 4000 Roskilde, Denmark. ${ }^{5}$ DTU Aqua, Technical University of Denmark, 2800 Kgs. Lyngby, DK, Denmark. ${ }^{6}$ Applied Physics Laboratory, Polar Science Center, University of Washington, Seattle, WA 98105-6698, USA. ${ }^{7}$ Greenland Institute of Natural Resources, Box 570, 3900 Nuuk, Greenland. ${ }^{8}$ Fisheries and Oceans Canada, Winnipeg, MB R3T 2N6, Canada. ${ }^{9}$ Smurfit Institute of Genetics, Trinity College Dublin, Dublin 2, Ireland. ${ }^{\circledR}$ email: Philippine.Chambault@gmail.com
} 
Traditionally narwhals have been considered tightly associated with sea ice ${ }^{14}$, and while this may be the case for some populations most narwhal populations spend 2-3 summer and fall months in ice-free areas but always in areas dominated by cold polar waters. Narwhals are generally considered to be among the most sensitive and vulnerable of Arctic endemic marine mammals to climate changes ${ }^{15}$ due to their choice of habitat, limited prey selection, strict migratory patterns and high site fidelity. At the same time, narwhals are hunted in Greenland and Canada where populations are monitored closely to detect changes that may by caused by the hunting pressure or the ongoing changes in the habitats. It is therefore important to understand the current habitat selection of narwhals and the climate drivers that may potentially change their habitats.

A marked variability in abundance estimates across population units have been highlighted from aerial surveys conducted at the different summer grounds, with localities in the CAA showing a greater abundance of narwhals $\left(>141,000\right.$ individuals) compared to West $(\sim 14,400)$ and East Greenland $(\sim 6400)^{16,17}$. The contrasting oceanographic conditions encountered at the different summer grounds as well as the hunting pressure may explain the demographic variability for the species.

Cold and buoyant waters from the CAA enter northern Baffin Bay and are transported southward towards Davis Strait along the western part of Baffin Bay along the Canadian coast, while a warm and salty subsurface current along the West Greenland coast transports dense Atlantic waters northward towards northern Baffin Bay $^{18}$. In comparison, East Greenland is characterized by the southward flowing East Greenland Current which transports cold water masses that are originally derived from the Arctic Ocean but are mixed with coastal runoffs from melting glaciers along East Greenland ${ }^{19}$. In addition, warm and saline Atlantic waters flowing northward between Iceland and East Greenland (the Irminger Current) in the Denmark Strait occasionally reach the East Greenland shelf break ${ }^{20}$. In a context of climate change, we therefore might assume that the population dynamics of narwhals are partly influenced by changes in environmental conditions, with warm areas with increasing sea temperatures having lower abundance of narwhals. This is supported by the narrow temperature habitat usage observed in narwhals in East Greenland ${ }^{21}$.

\section{Materials and methods}

Study areas and tag deployment. Live-capture operations of narwhals were conducted in collaboration with Inuit hunters in Northeastern Canada, West and East Greenland. Set nets of 40 to $80 \mathrm{~m}$ length and 5 to $8 \mathrm{~m}$ deep were deployed from shore to an anchor at suitable sites. Lookouts for whales were maintained from landbased promontories, from which the nets were kept under constant diurnal surveillance. As soon as there were indications of a whale being entangled, the net was released from the anchor and the whale pulled to the surface and towards the shore where instrumentation took place. Sex of the whales was determined based on presence (male) or absence (female) of a tusk. Various generations of Wildlife Computers (Redmond, Seattle, WA, USA) SLTDR, SPOT tags and FastLoc transmitters were mounted on the tusk or for the majority of the whales on the keratinized dorsal ridge of the whales with 2-3 delrin nylon pins ( $8 \mathrm{~mm}$ diameter) secured with nylon washers and bolts on each end ${ }^{22,23}$.

Location processing. Location data were relayed through the Argos Data Collection and Location System and decoded using Argos Message Decoder (DAP Ver. 3.0, build 114, Wildlife Computers). The least-square filtering algorithm was used for the Argos data until 2011, after which Kalman filtering was used. All statistical analyses were performed using $\mathrm{R}$ software version 3.6.2 ${ }^{24}$. The modelling approach of Albertsen et al. ${ }^{25}$ implemented in the R package $\operatorname{argos} \operatorname{rack}^{26}$ was applied to the tracking data to improve the estimation of the whale's actual tracks from Argos locations. Tracks were estimated separately for each individual using a step-wise approach simplifying the estimation model if convergence issues were encountered, for instance for short tracks. Initially, the estimation assumed a continuous time-correlated random walk movement model with t-distributed measurement error. Variance parameters were estimated for each Argos location class. If the model did not converge properly, the ratio between variance parameters was fixed following the results of Albertsen et al. ${ }^{25}$. Subsequently, a multivariate normal distribution was used for the measurement error with and without free variance parameters. Finally, if a model still had not converged, a random walk movement model was used with and without free measurement variance parameters. In 2015, 2017 and 2018, Fastloc GPS transmitters were used and no estimation model was applied to their more precise GPS positions ${ }^{27,28}$. In order to assess temporal patterns, seasons were discriminated as follows: autumn from October to December, winter from January to March, spring from April to June and summer from July to September. To assess the influence of rising sea temperatures on narwhals we focused on the summer period which corresponds to peak of ocean temperatures in the Arctic.

Environmental data. We extracted environmental variables from model simulations to characterize the habitat experienced by the narwhals. The associated Sea Surface Temperature (SST) and Sea Ice Concentration (SIC) data were first extracted daily from the products Global Ocean Physics Reanalysis Glorys S2V4 (PHYS 001-024) and the Global Ocean Physics Reanalysis Glorys12v1 (PHY-001-030) at a resolution of $0.08^{\circ}$ (from E.U. Copernicus Marine Service Information) at each whale location. In order to generate time-series of SST and SIC between 1993 and 2018, monthly grids of both variables were also extracted from the products Global Ocean Physics Reanalysis Glorys12v1 (PHY-001-030) and Global Ocean and Physics Analysis Forecast (PHY-001-024) and averaged over the extension of each of 17 summer foraging grounds with narwhal aggregations. The monotonic SST trends were then assessed for each summer ground using the trend package ${ }^{29}$.

Abundance data. Narwhals have strong site fidelity to their coastal summer grounds and narwhal aggregations are defined based on their summer distribution ${ }^{13,30}$. Abundance estimates that were obtained in previous studies (from 11 of the 17 summer grounds, Table 1) where more than one abundance was available were used 


\begin{tabular}{|c|c|c|c|c|c|c|c|c|c|c|}
\hline \multirow[b]{2}{*}{ Stock } & \multirow[b]{2}{*}{ SG } & \multirow[b]{2}{*}{ Sector } & \multirow[b]{2}{*}{ Year } & \multirow{2}{*}{$\begin{array}{l}\text { Area } \\
\left(\mathrm{km}^{2}\right)\end{array}$} & \multirow{2}{*}{\begin{tabular}{|l|} 
Estimate \\
(whales) \\
\end{tabular}} & \multirow[b]{2}{*}{$\mathrm{CV}$} & \multirow{2}{*}{\begin{tabular}{|l|} 
Density \\
(whales/km²) \\
\end{tabular}} & \multirow[b]{2}{*}{ CR } & \multirow{2}{*}{$\begin{array}{l}\text { SST } \\
\left({ }^{\circ} \mathrm{C}\right) \\
\end{array}$} & \multirow[b]{2}{*}{ References } \\
\hline & & & & & & & & & & \\
\hline Peel sound & PS & CAA & 1996 & 14,735 & 5240 & 0.6 & 0.36 & 0.022 & -0.89 & 55 \\
\hline Peel sound & PS & CAA & 2013 & 5454 & \begin{tabular}{|l|}
17,003 \\
\end{tabular} & 0.21 & 3.12 & 0.039 & 0.39 & 17 \\
\hline Barrow strait & BS & CAA & 1996 & 27,405 & 5898 & 0.75 & 0.22 & 0.022 & -1.05 & 55 \\
\hline Barrow strait & BS & CAA & 2004 & 21,599 & 2925 & 0.46 & 0.14 & 0.022 & -0.69 & 56 \\
\hline $\begin{array}{l}\text { Prince regent } \\
\text { inlet }\end{array}$ & PRI & CAA & 1996 & 29,296 & 34,159 & 0.35 & 1.17 & 0.036 & 0.33 & 55 \\
\hline $\begin{array}{l}\text { Prince regent } \\
\text { inlet }\end{array}$ & PRI & CAA & 2002 & 30,628 & 20,871 & 0.71 & 0.68 & 0.036 & -0.62 & 56 \\
\hline $\begin{array}{l}\text { Prince regent } \\
\text { inlet }\end{array}$ & PRI & CAA & 2013 & 29,178 & 10,668 & 0.63 & 0.37 & 0.036 & 1.29 & 17 \\
\hline Gulf of Bothia & GB & $\mathrm{CAA}$ & 2002 & 56,567 & 6770 & 0.3 & 0.12 & 0.033 & -0.26 & 56 \\
\hline Gulf of Bothia & GB & CAA & 2013 & 63,178 & 21,574 & 0.28 & 0.34 & 0.033 & 0.74 & 17 \\
\hline $\begin{array}{l}\text { Admiralty } \\
\text { inlet }\end{array}$ & AI & CAA & 2003 & 9464 & 5362 & 0.5 & 0.57 & 0.011 & 2.22 & 17 \\
\hline $\begin{array}{l}\text { Admiralty } \\
\text { inlet }\end{array}$ & AI & CAA & 2010 & 8159 & 18,049 & 0.23 & 2.21 & 0.011 & 2.24 & 57 \\
\hline $\begin{array}{l}\text { Admiralty } \\
\text { inlet }\end{array}$ & AI & CAA & 2013 & 9419 & 35,043 & 0.42 & 3.72 & 0.011 & 2.59 & 17 \\
\hline Eclipse sound & ES & CAA & 2004 & 6690 & 20,225 & 0.36 & 3.02 & 0.12 & -0.43 & 56 \\
\hline Eclipse sound & ES & CAA & 2013 & 8459 & 10,489 & 0.24 & 1.24 & 0.12 & 2.13 & 17 \\
\hline $\begin{array}{l}\text { East Baffin } \\
\text { Island }\end{array}$ & $\mathrm{EB}$ & CAA & 2003 & 11,204 & 10,073 & 0.31 & 0.9 & 0.13 & 0.49 & 56 \\
\hline $\begin{array}{l}\text { East Baffin } \\
\text { Island }\end{array}$ & EB & CAA & 2013 & 53,510 & 17,555 & 0.35 & 0.33 & 0.13 & 4 & 17 \\
\hline Melville Bay & MB & Northwest & 2012 & 14,821 & 2983 & 0.31 & 0.2 & 0.2 & 5.4 & 58 \\
\hline Melville Bay & MB & Northwest & 2014 & 14,821 & 3091 & 0.5 & 0.21 & 0.2 & 4.66 & 58 \\
\hline Tasiilaq & TAS & Southeast & 2008 & 2966 & 206 & 0.55 & 0.07 & \begin{tabular}{|l|}
0.071 \\
\end{tabular} & 6.35 & 59 \\
\hline Tasiilaq & TAS & Southeast & 2016 & 5401 & 0 & 0 & 0 & 0.071 & 9.49 & 59 \\
\hline Kangerlussuaq & KAN & Southeast & 2008 & 672 & 613 & 0.71 & 0.31 & 0.11 & 5.34 & 59 \\
\hline Kangerlussuaq & KAN & Southeast & 2016 & 667 & 269 & 0.37 & 0.06 & 0.11 & 8.33 & 59 \\
\hline $\begin{array}{l}\text { Scoresby } \\
\text { sound }\end{array}$ & SCS & Mideast & 2008 & 11,144 & 1945 & 0.57 & 0.17 & 0.13 & 3.1 & 59 \\
\hline $\begin{array}{l}\text { Scoresby } \\
\text { sound }\end{array}$ & SCS & Mideast & 2016 & 9828 & 433 & 0.49 & 0.04 & 0.13 & 6.04 & 59 \\
\hline $\begin{array}{l}\text { Scoresby } \\
\text { sound }\end{array}$ & SCS & Mideast & 2017 & 7927 & 246 & 0.43 & 0.03 & 0.13 & 5.52 & 59 \\
\hline
\end{tabular}

Table 1. Abundance estimates for the 11 localities. SG refers to the summer ground's abbreviation, CV to coefficient of variation and CR to the coefficient of regression of the SST trend over time extracted for each stock.

in the analysis. The methods used for obtaining the abundance estimates are described in Heide-Jørgensen ${ }^{16}$ and Doniol-Valcroze ${ }^{17}$. The estimates were used to relate whales' abundance and density (whales $/ \mathrm{km}^{2}$ ) to SST, and assess the effect of temperature on the abundance and densities of narwhals. SST data in August (month of the abundance surveys) were extracted at each summer ground for each sampled year. The relationships between abundance and SST and whale density and SST were then investigated using a linear non-parametric Theil-Sen regression model from the $\mathrm{mblm}$ package ${ }^{31}$. To assess the relation between SST change over time and the abundance of narwhals, the SST slope derived from each summer ground over the entire period (1993 to 2018) was related to the estimates of narwhal abundance and density separately.

\section{Results}

Temperature affinities at the narwhals' tracks. From 1993 to 2019, a total of 144 narwhals were satellite-tracked in summer in Canadian Arctic Archipelago $(n=68)$, West Greenland $(n=21)$ and East Greenland $(\mathrm{n}=55)$ - see Fig. 1 and Table SI1.

In summer, narwhals tracked from populations in West Greenland and in the CAA dispersed widely across Baffin Bay, northern Baffin Island and within the fjords of the CAA. The narwhals that were tracked from populations in East Greenland remained close to or just south of the Scoresby Sound summer ground (Mideast of Greenland).

The habitat encountered by the narwhals tracked from populations in the CAA, West and East Greenland differed in summer. Narwhals from West Greenland and CAA experienced significantly cooler sea surface temperatures during summer (ranging between -2 and $4{ }^{\circ} \mathrm{C}$, Kruskal-Wallis test, $p<0.001$, Fig. $2 \mathrm{a}$ ) associated with significantly higher sea-ice concentrations (up to $>99 \%$, Fig. 2b, Kruskal-Wallis test, $p<0.001$ ). By comparison, 


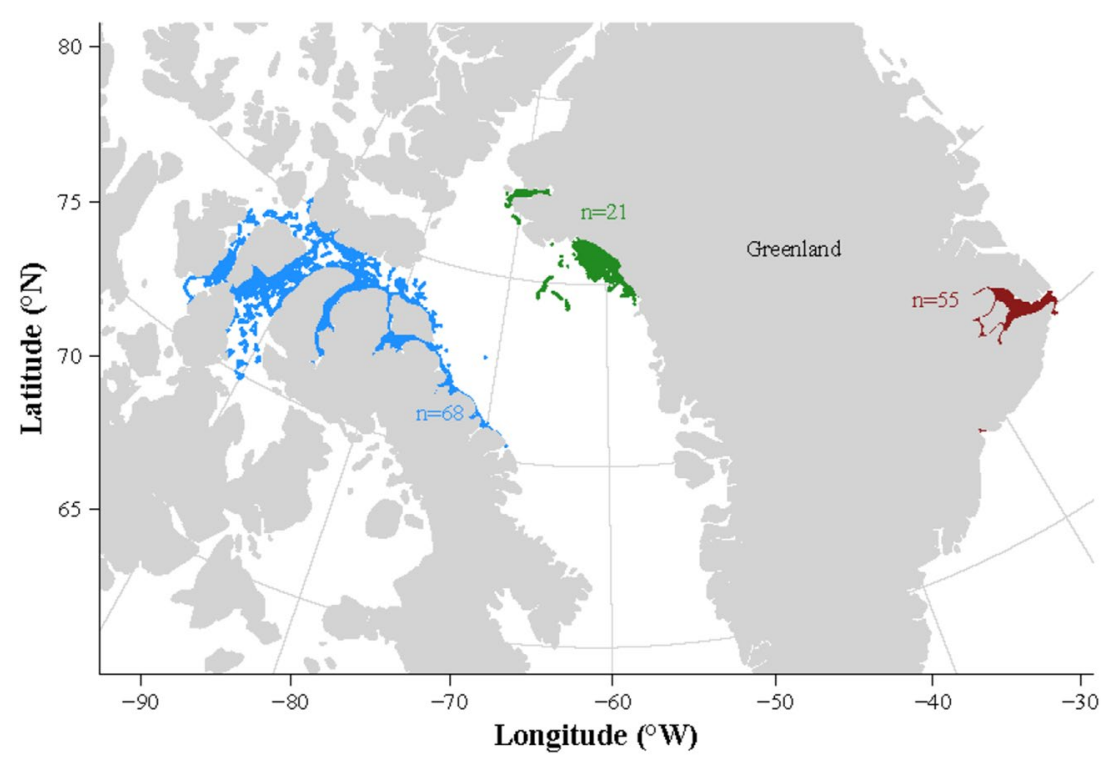

Figure 1. Summer distribution of narwhals' tracks in the three tagging areas: the Canadian Arctic Archipelago, blue dots), West Greenland (green dots) and East Greenland (red dots). The number of tracked narwhals is indicated in each colour.

a) Sea surface temperature at locations

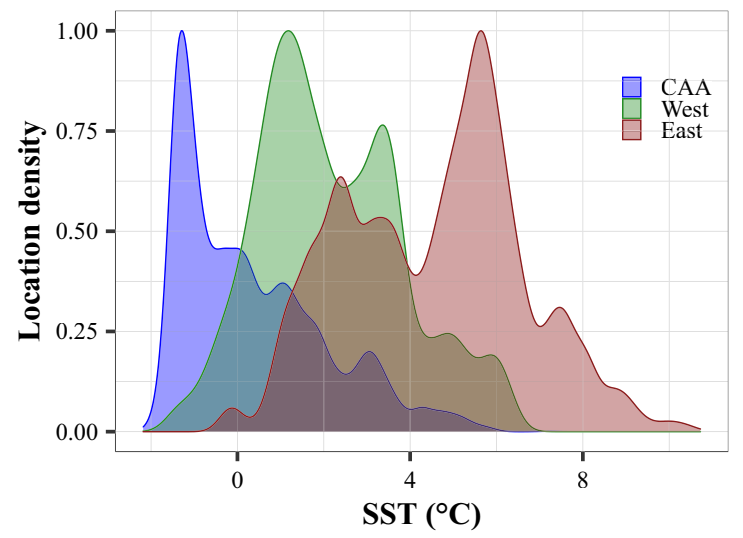

b) Sea ice concentration at locations

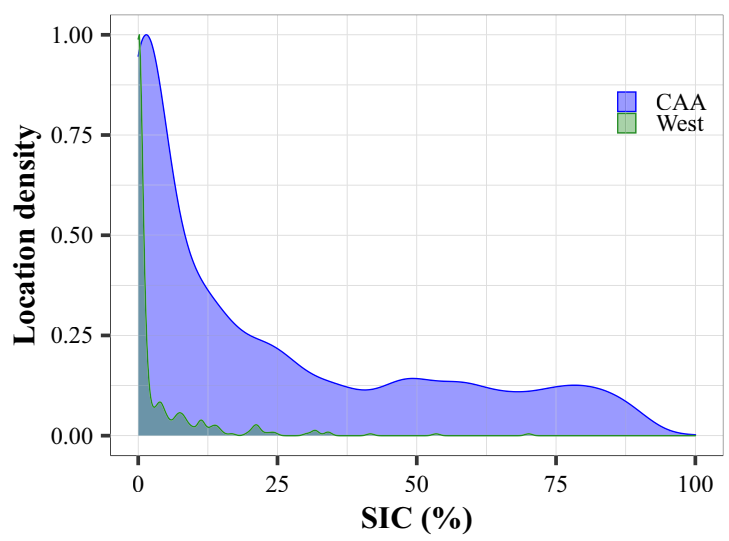

Figure 2. Histograms of (a) sea surface temperature and (b) sea ice concentration extracted at each narwhal location for CAA (in blue), West (in green) and East (in red) in summer.

narwhals in East Greenland experienced significantly warmer SSTs (range: 0 to $10{ }^{\circ} \mathrm{C}$, Kruskal-Wallis test, $p<0.001$ ) and no sea-ice concentrations in summer (Fig. 2b).

Temperature trends at the summer grounds. A total of 17 summer grounds are used by narwhal populations in Canada and Greenland (Fig. 3), with eight summer grounds (HB, GB, PS, PRI, BS, AI, ES and EB) in the central CAA, two in the northern part of the CAA (JS and SS), and two others in Northwest Greenland (IB and $\mathrm{MB}$ ). In East Greenland there are two summer grounds (GS and DB) in the Northeast, one in the Mideast (SCS), and two in the Southeast Greenland (KAN and TAS).

The SST trends on the summer grounds differed according to the areas (Fig. 4) and are presented in Table 2. In the central and northern parts of the CAA and Baffin Bay, SST was relatively stable across years. The Mann-Kendall tests confirmed this monotonic trend in the CAA, as it was non-significant for all localities except EB (Mann-Kendall test: $p<0.005)$ and ES (Mann-Kendall test: $p<0.005$, Fig. $4 \mathrm{a}$ ). The trend was significant in the two North Baffin Bay localities (SS, JS, Mann-Kendall test, $p<0.05$, Fig. 4b). In contrast, SST increased over time in all localities in Northwest Greenland (IB, MB, Mann-Kendall test: $p<0.001$, Fig. 4c), Mideast (SCS, Mann-Kendall test: $p<0.001$, Fig. $4 \mathrm{e}$ ) and Southeast Greenland (KAN, TAS, Mann-Kendall test for KAN and TAS: $p<0.001$ and $p=0.1$, respectively, Fig. 4f). Finally, in Northeast Greenland, the SST increased for DB (Mann-Kendall test: $p<0.005$ ) whereas it was steady for GS (Mann-Kendall test: $p=0.48)$ - see Fig. $4 \mathrm{~d}$. 


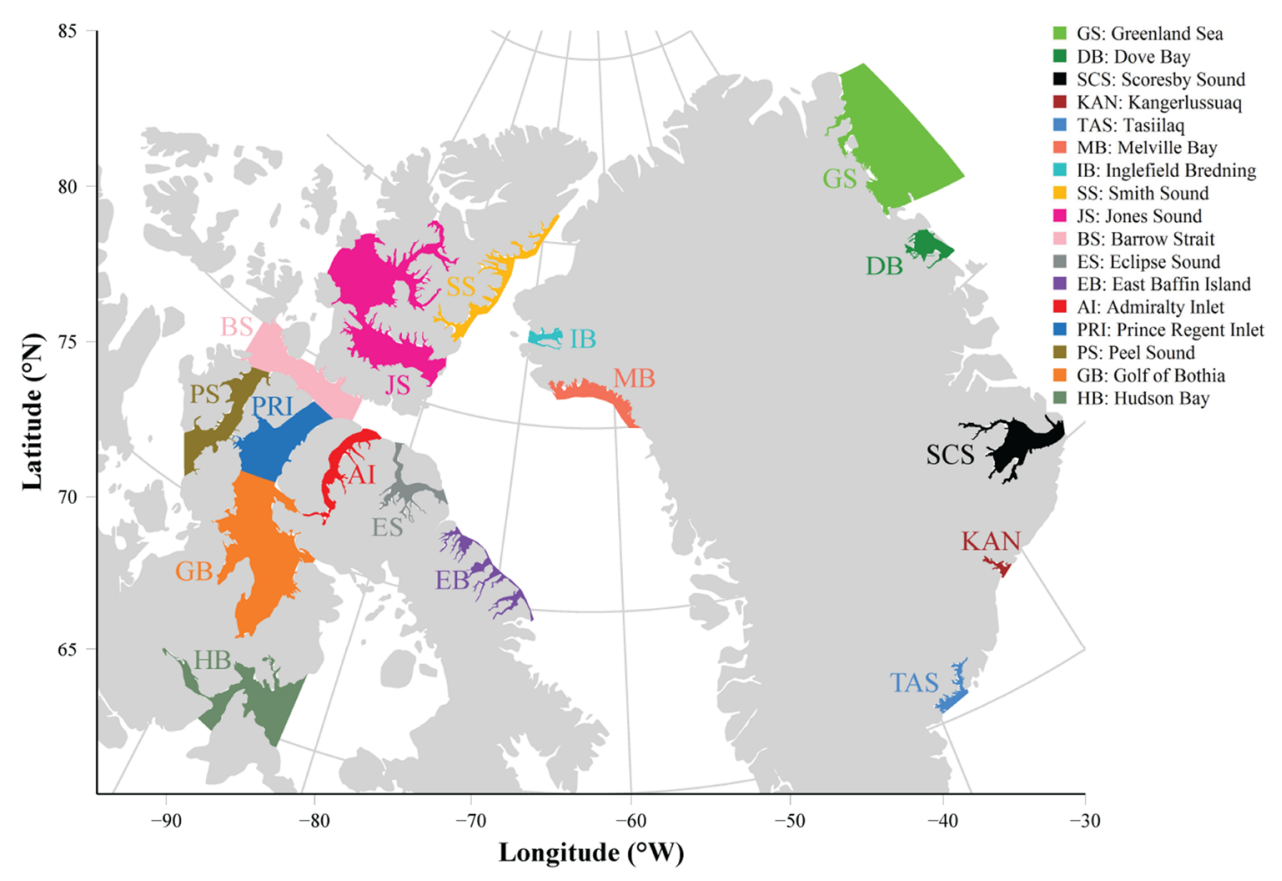

Figure 3. Map of 17 narwhal summer grounds in Canada and Greenland. The extent of the summer grounds reflects the summer distribution of whales as delimited by abundance surveys. Summer ground areas were used for estimating the annual trends in SST.

a) Canadian Arctic Archipelago

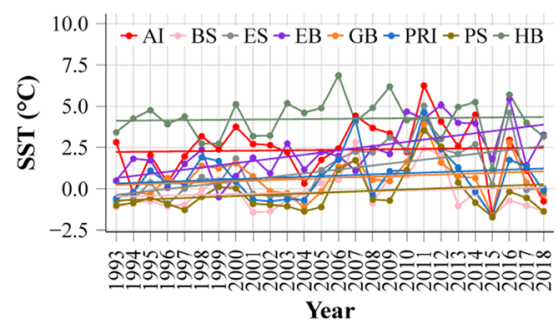

d) Northeast Greenland

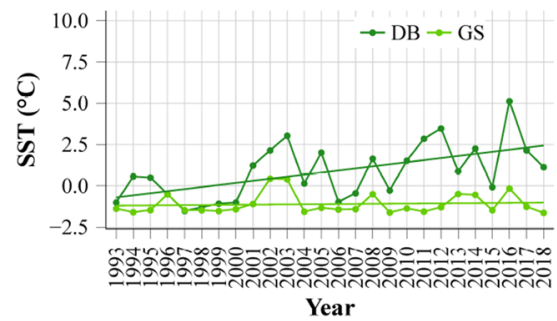

b) North Baffin Bay

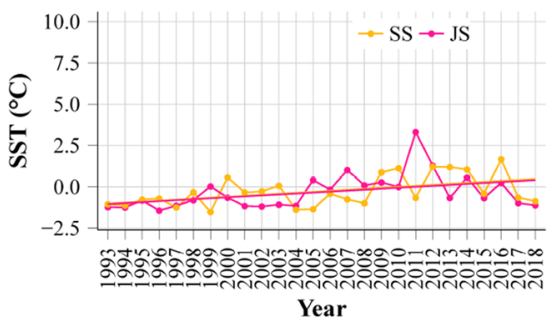

e) Mideast Greenland

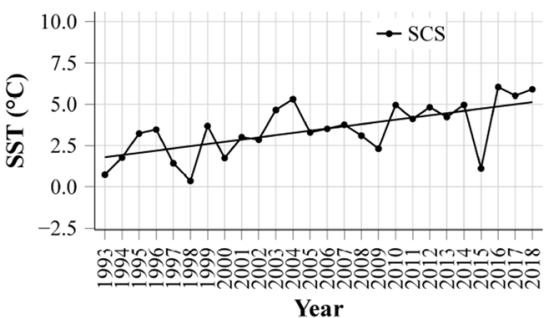

c) Northwest Greenland

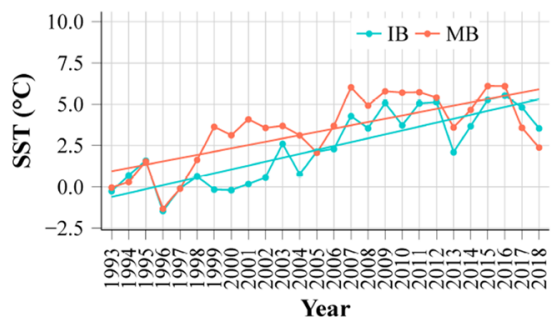

f) Southeast Greenland

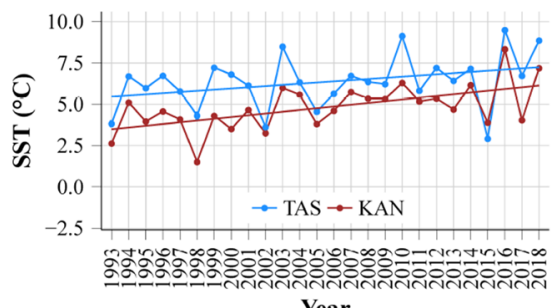

Year

Figure 4. Trends in August SST values (means) between 1993 and 2018 for the summer grounds located in (a) the Canadian Arctic Archipelago (CAA), (b) North of Baffin Bay, (c) Northwest Greenland, (d) Northeast Greenland, (e) Mideast Greenland and (f) Southeast Greenland.

To test this hypothesis, we used a large dataset comprised of 144 satellite-tracked narwhals (Table SI1), sea surface temperatures (SST) data spanning 25 years (1993-2018) and population abundance estimates from 17 localities. This study aimed to (1) assess the thermal preference of this cold-adapted species, (2) investigate the temperature trends at its summer foraging grounds, and to finally (3) assess the relationship between sea temperatures and abundance of narwhals.

Relationship between SST and narwhal abundance. To increase the robustness of the results, the summer grounds containing less than two abundance estimates were not included in the analysis (HB, IB, SS, 


\begin{tabular}{|l|l|l|c|}
\hline Sector & SG & Trend & $p$ value \\
\hline CAA & AI & $0.011 \mathrm{x}+2.2$ & 0.822 \\
\hline CAA & BS & $0.022 \mathrm{x}-0.49$ & 0.493 \\
\hline CAA & EB & $0.13 \mathrm{x}+0.52$ & $<0.001$ \\
\hline CAA & ES & $0.12 \mathrm{x}-0.48$ & $<0.005$ \\
\hline CAA & GB & $0.033 \mathrm{x}+0.21$ & 0.297 \\
\hline CAA & HB & $0.0092 \mathrm{x}+4.1$ & 0.778 \\
\hline CAA & PRI & $0.036 \mathrm{x}+0.29$ & 0.357 \\
\hline CAA & PS & $0.039 \mathrm{x}-0.75$ & 0.246 \\
\hline North Baffin & JS & $0.058 \mathrm{x}-1.1$ & 0.034 \\
\hline North Baffin & SS & $0.06 \mathrm{x}-1.1$ & 0.011 \\
\hline Northwest & IB & $0.24 \mathrm{x}-0.84$ & 5.232 \\
\hline Northwest & MB & $0.2 \mathrm{x}+0.74$ & $<0.001$ \\
\hline Northeast & GS & $0.0074 \mathrm{x}-1.2$ & 0.651 \\
\hline Northeast & DB & $0.13 \mathrm{x}-0.83$ & $<0.005$ \\
\hline Mideast & SCS & $0.13 \mathrm{x}+1.7$ & $<0.001$ \\
\hline Southeast & KAN & $0.11 \mathrm{x}+3.4$ & $<0.005$ \\
\hline Southeast & TAS & $0.071 \mathrm{x}+5.4$ & 0.092 \\
\hline
\end{tabular}

Table 2. Summary of the SST trends for each summer foraging ground (SG) with the associated $p$ values.

JS, DB and GS) - See Table 1. In the CAA, the SST was much lower compared to all other localities (mean \pm SE: $0.7 \pm 0.3{ }^{\circ} \mathrm{C}$ vs. $6.0 \pm 0.6^{\circ} \mathrm{C}$, Fig. $5 \mathrm{a}$ ). Whale abundance was also higher in the CAA (mean \pm SE: $15,119 \pm 2450$ whales), and minimal in the Mideast ( $874 \pm 537$ whales) and Southeast Greenland (272 \pm 127 whales) summer grounds (Fig. 5a). Similarly, narwhal density was highest in the CAA $\left(1.15 \pm 0.29\right.$ whales $\left.\mathrm{km}^{-2}\right)$, and lowest in the Mideast Greenland (0.08 \pm 0.04 whales km ${ }^{-2}$, Fig. 5b).

Whale abundance was inversely related to SST (Fig. $5 c$ ). The whale density also decreased with increasing sea temperatures (Fig. 5d). For both relationships, the Theil-Sen regression model was significant $(p<0.001$ for abundance and $p<0.05$ for density). Similarly, Theil-Sen regressions were significant when considering only the latest estimate for each locality (Fig. 5c,d, grey dotted lines). When looking at the SST trend, the narwhals' abundance and density decreased with SST slope evaluated over the entire period (1993-2018) (Fig. 5e,f).

\section{Discussion}

A narrow thermal preference. We have demonstrated that narwhal densities are highest for a narrow range of sea temperatures. These results are in agreement with a previous study conducted on bowhead whales (Balaena mysticetus) in the same region ${ }^{32}$, and suggest a limited thermal preference of Arctic cetaceans. Despite the limited thermal range on both sides of Greenland, the temperature exposure was four degrees higher in East Greenland compared to West Greenland and the Canadian Arctic Archipelago (CAA). Increasing water temperatures and sea-ice loss are expected to strongly modify the seasonality, distribution, and concentration of prey targeted by apex predators such as the narwhal and the bowhead whale, thus, potentially threatening the survival of these Arctic cetaceans ${ }^{33}$.

Narwhals feed on polar cod (Boreogadus saida), Arctic cod (Arctogadus glacialis) and squid (Gonatus fabricii) in all areas, and in Baffin Bay they also target Greenland halibut (Reinhardtius hippoglossoides) ${ }^{34}$. A recent study in the Chukchi Sea showed that the abundance of the small-size cod (one of the narwhal's main prey) peaked between 4 and $5^{\circ} \mathrm{C}^{35}$, and cold temperatures $\left(<2{ }^{\circ} \mathrm{C}\right)$ are known to favour the growth of the juvenile Arctic $\operatorname{cod}^{36}$. On the wintering grounds in Baffin Bay, narwhals are assumed to be feeding on Greenland halibut that are most abundant at cool bottom temperatures of $0.5-1.0^{\circ} \mathrm{C}^{37}$. Over the long-term, increasing water temperature might therefore reduce the prey biomass available for narwhals, forcing this species to shift habitat or prey.

A question also remains regarding the direct consequence of oceanic warming on the physiology of this coldadapted species by over-heating. With a thermal conductivity of water 25 times that of air, heat loss in marine mammals is much faster than in air of the same temperature ${ }^{38}$. Whales have a thick subcutaneous fat deposit (blubber) that prevents excessive heat loss and functions as thermal insulation and energy reserve ${ }^{39}$. Cetaceans dispose excess heat from poorly insulated peripheral areas, such as fins and tail flukes, that are utilized as thermal windows through which heat can be exchanged via conduction and convection ${ }^{40}$. Similar to bowhead whales, narwhals maintain thick blubber layer and lack a dorsal fin to serve as a thermal window for dissipating excess heat. As oceanic temperatures rise, these extreme adaptations that enable polar living may serve as a liability for narwhals, especially as the ice cover becomes more unpredictable ${ }^{41}$, and preferred prey move to new areas or depths. Their limited physiological flexibility also prevents them from adjusting their swimming and diving behaviour to climate change via shifts in habitats and prey selections ${ }^{41}$.

Studies of thermal habitat preference in narwhals have shown an extreme selection of a very narrow temperature range where the whales avoid water masses with temperatures above $2{ }^{\circ} \mathrm{C}^{21}$. The blubber insulation evidently protects the whales from hypothermia but the thermal niche also suggests that excess heat production during elevated locomotion activity can be a problem for the whales. Unlike bowhead whales, narwhals show a 
a)

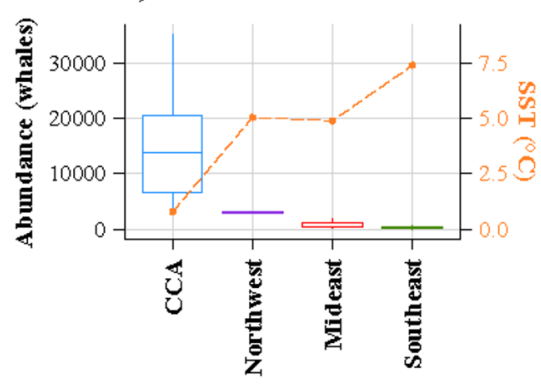

c)

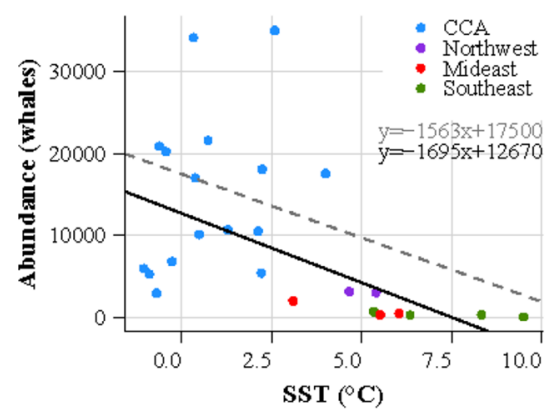

e)

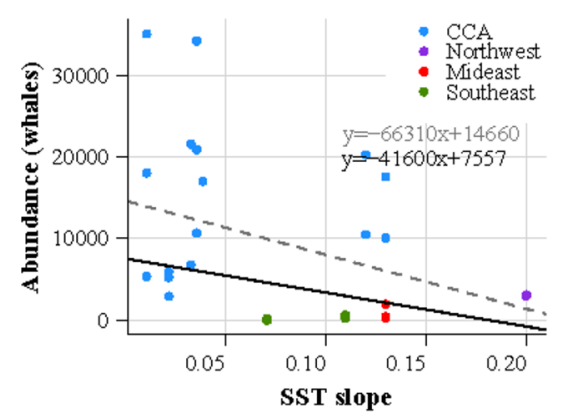

b)

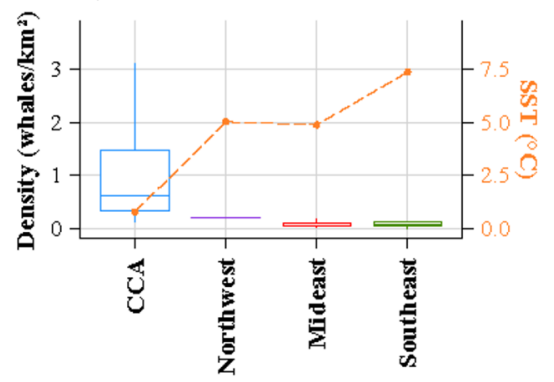

d)

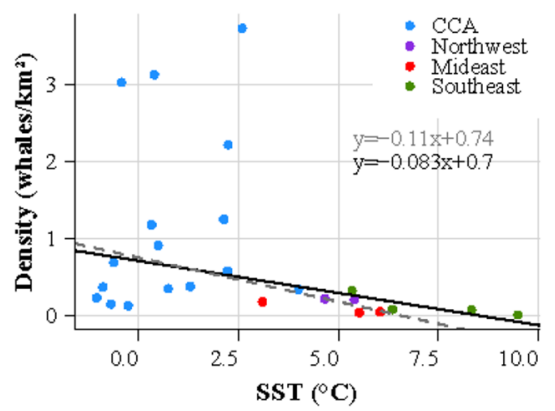

f)

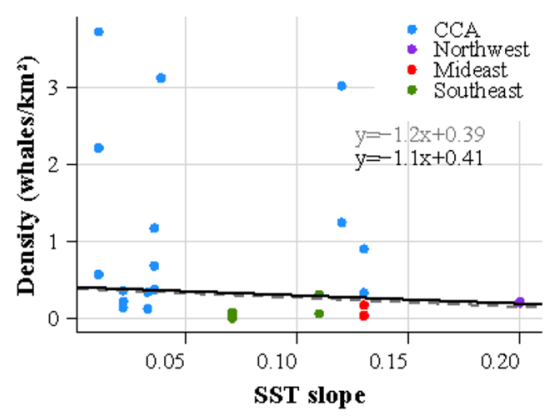

Figure 5. Boxplots of (a) narwhal abundance and (b) narwhal density for the four sectors where abundance data were available. The horizontal lines in the box plots refer to the medians, and the dotted orange lines in (a) and (b) to the mean SST for each sector. Scatterplots showing the relationship between narwhal abundance and (c) SST and (e) SST slope, and narwhal density and (d) SST and (f) SST slope. The Theil-Sen regression lines are shown in black and grey with the corresponding equation. The black lines refer to the Theil-Sen regressions including all estimates for each sector, and the grey dotted lines to the latest estimate for each locality. Each dot represents an abundance estimate from the 11 summer grounds that contained more than one estimate.

limited behavioural plasticity in their movement patterns ${ }^{22,23,30}$. Bursts of high levels of exercise and consequent heat production in connection with normal foraging behaviour or due to anthropogenic disturbance exacerbate the problem of temperature regulation. Together, thick blubber insulation, the lack of a dorsal fin coupled with a warming environment may limit the ability of Arctic cetaceans to remove excess heat and prevent hyperthermia. The strong site fidelity to their summer grounds might also limit their ability to adapt to a changing environment. Narwhals from East Greenland are in a particularly challenging situation due to the elevated temperature optimum compared to West Greenland and the CAA. Based on this, further studies are needed concerning the thermal physiology of Arctic cetaceans in general.

Consequences of climate change on whale abundance. A sharp increase in sea temperature was observed in the Northwest, Mideast and Southeast of Greenland, whereas no change occurred in the CAA, which is in agreement with the predictions of thermal suitable habitats. Unlike the warm and saline Atlantic waters that are responsible for the rising temperatures in Northwest Greenland ${ }^{18}$, the cold CAA waters originate from the polar basin, ice melt and river discharges ${ }^{42}$, which explains the stable temperatures. Similarly to the Northwest, Mideast Greenland was characterized by a sharp temperature increase over time, as the result of warm Atlantic waters flowing northward between Iceland and East Greenland ${ }^{20}$. In addition, the southward transport of multiyear sea ice from Fram Strait along East Greenland has been severely reduced over the three past decades ${ }^{43}$. 
Considering the extreme dependency of narwhals on cold water habitats, it is perhaps not surprising that the largest narwhal abundances are found in areas that meet these specifications, and that localities where increasing sea surface temperatures have been detected, host the smallest populations. Recent survey efforts have documented surprisingly large abundances of narwhals in areas that have not been surveyed before, but from where little or no historical evidence of narwhal concentrations is available. These areas include Dove Bay, Northeast Greenland, Smith Sound and Jones Sound, and although no systematic efforts to document narwhal populations in these areas have been conducted, the new abundance estimates indicate a possible shift in distribution. In Dove Bay, for instance, a 3-year expedition from 1906 to 1908 failed to detect any narwhals, whereas a survey conducted in 2017 estimated approximately 2000 narwhals in the bay ${ }^{44}$. Similarly, new abundance estimates of about 16,000 and 13,000 narwhals in the cold regions of Smith Sound and Jones Sound have not been documented before and these estimates are extremely high compared to past information from these areas ${ }^{45-47}$.

Trends in narwhal populations due to habitat changes are difficult to assess as some of the populations are also hunted, which affects population trends to varying degrees ${ }^{48,49}$. Trajectories of trends for narwhal populations in Mideast and Southeast Greenland show with high probability that these populations have never been large compared to populations in CAA and Northwest Greenland. Due to their low present abundance they are particularly vulnerable to overexploitation ${ }^{13}$. Southeast Greenland is at the same time the area with the most pronounced increases in SST. In comparison with the larger narwhal populations in the CAA and Northwest Greenland. The small size of the populations and increasing SST emphasizes the need for restrictive management of the exploitation of the populations in Mideast and Southeast Greenland. Independent of the history of exploitation, the magnitude of the differences in population sizes reflects the actual importance and habitat suitability of the localities. Of particular significance is the narwhal population in Southeast Greenland that is affected by a regime shift in oceanography with warming temperatures in coastal areas and a reduced transport of polar pack-ice along the East Greenland coast. Although excessive hunting occurs in Southeast Greenland, the decline or disappearance of narwhals from previously used summer grounds and the shift of hunting effort to more northern and presumably colder areas indicates that Southeast Greenland may no longer be a suitable habitat for narwhals ${ }^{50}$.

\section{Conclusion}

By combining telemetry data to abundance estimates and sea surface temperatures we were able to assess (1) the thermal exposure, (2) the SST trends at the summer foraging grounds, and (3) the relationship between SST and abundance of a cold-adapted species, the narwhal. Despite the observation of widespread increase in temperature over the Arctic, the SST time series (from 1993 to 2018) indicate different trends across the summer grounds, with a noticeable correlation between increasing sea temperatures and the whales' abundance. These results support the hypothesis that warming ocean waters will restrict the habitat range of this Arctic cetacean, further suggesting that narwhals from Mideast and Southeast Greenland may be under pressure to abandon their traditional habitats due to ocean warming, and consequently either migrate further North, or locally go extinct. In addition to indirect effects on their distribution, rising temperatures may affect the whales through physiological stress. To survive in cold environments, polar marine species have developed morphological adaptations to provide thermal insulation through dense plumage, thick fur ${ }^{51}$ or a blubber layer ${ }^{52}$. Cetaceans endemic to the Arctic also lack a dorsal fin, which in boreal species serves to dissipate heat ${ }^{53}$. These morphological specialisations allow travel in ice-covered areas, but may represent a morphological handicap for transferring excess body heat compared to sub-Arctic cetacean species ${ }^{54}$ such as the harbour porpoise and humpback whale. Warmer temperatures could therefore represent a potential thermal challenge for Arctic cetaceans with no dorsal fin such as narwhals and bowhead whales, and warrants further investigation.

Received: 9 January 2020; Accepted: 14 October 2020

Published online: 29 October 2020

\section{References}

1. Alexander, M. A. et al. Projected sea surface temperatures over the 21 st century: changes in the mean, variability and extremes for large marine ecosystem regions of Northern Oceans. Elem. Sci. Anth. 6, 9 (2018).

2. National Snow \& Ice Data Center. State of the cryosphere: is the cryosphere sending signals about climate change? https://nsidc .org/cryosphere/sotc/sea_ice.html (2020). Accessed 24 Apr 2020.

3. Michel, C. et al. Biodiversity of Arctic marine ecosystems and responses to climate change. Biodiversity 13, 200-214 (2012).

4. Hauser, D. D. W., Laidre, K. L. \& Stern, H. L. Vulnerability of Arctic marine mammals to vessel traffic in the increasingly ice-free Northwest Passage and Northern Sea Route. Proc. Natl. Acad. Sci. 115, 7617-7622 (2018).

5. Albouy, C. et al. Global vulnerability of marine mammals to global warming. Sci. Rep. 10, 1-12 (2020).

6. Dietz, R., Heide-Jørgensen, M. P., Glahder, C. \& Born, E. Occurrence of narwhals (Monodon monoceros) and white whales (Delphinapterus leucas) in East Greenland. Meddr. Grønl. Biosci. 39, 69-86 (1994).

7. Dietz, R., Heide-Jørgensen, M. P., Richard, P. R. \& Acquarone, M. Summer and Fall Movements of Narwhals (Monodon monoceros) from Northeastern Baffin Island Towards Northern Davis Strait. Arctic 54, 244-261 (2001).

8. Richard, P., Weaver, P., Dueck, L. \& Barber, D. Distribution and numbers of Canadian High Arctic narwhals (Monodon monoceros) in August 1984. Meddr. Grønl. Biosci. 39, 41-50 (1994).

9. Dietz, R. \& Heide-Jørgensen, M. P. Movements and swimming speed of narwhals, Monodon monoceros, equipped with satellite transmitters in Melville Bay, northwest Greenland. Can. J. Zool. 73, 2106-2119 (1995).

10. Belikov, S. E. \& Boltunov, A. N. Distribution and migrations of cetaceans in the Russian Arctic according to observations from aerial ice reconnaissance. NAMMCO Sci. Publ. 4, 69-86 (2002).

11. Vacquié-Garcia, J. et al. Late summer distribution and abundance of ice-associated whales in the Norwegian High Arctic. Endanger. Species Res. 32, 59-70 (2017). 
12. Heide-Jørgensen, M., Richard, P. R., Dietz, R. \& Laidre, K. L. A metapopulation model for Canadian and West Greenland narwhals. Anim. Conserv. 16, 331-343 (2013).

13. Hobbs, R. C. et al. Global review of the conservation status of Monodontid stocks. Mar. Fish. Rev. 81, 1-41 (2020).

14. Kovacs, K. M. \& Lydersen, C. Climate change impacts on seals and whales in the North Atlantic Arctic and adjacent shelf seas. Sci. Prog. 91, 117-150 (2008).

15. Laidre, K. L. et al. Quantifying the sensitivity of Arctic marine mammals to climate-induced habitat change. Ecol. Appl. 18, S97S125 (2008).

16. Heide-Jørgensen, M. et al. Abundance of narwhals (Monodon monoceros) on the hunting grounds in Greenland. J. Mammal. 91, 1135-1151 (2010).

17. Doniol-Valcroze, T. et al. Abundance Estimates of Narwhal Stocks in the Canadian High Arctic in 2013 (NAMMCO Sci. Publ. 11, in press).

18. Münchow, A., Falkner, K. K. \& Melling, H. Baffin Island and West Greenland Current Systems in northern Baffin Bay. Prog. Oceanogr. 132, 305-317 (2015).

19. Sutherland, D. A. \& Pickart, R. S. The East Greenland coastal current: structure, variability, and forcing. Prog. Oceanogr. 78, 58-77 (2008).

20. Håvik, L. et al. Structure and variability of the Shelfbreak East Greenland current North of Denmark Strait. J. Phys. Oceanogr. 47, 2631-2646 (2017).

21. Heide-Jørgensen, M. P. et al. Some like it cold: temperature-dependent habitat selection by narwhals. Ecol. Evol. 10, 8073-8090 (2020).

22. Heide-Jørgensen, M. P. et al. The migratory behaviour of narwhals (Monodon monoceros). Can. J. Zool. 81, 1298-1305 (2003).

23. Dietz, R. et al. Movements of narwhals (Monodon monoceros) from Admiralty Inlet monitored by satellite telemetry. Polar Biol. 31, 1295-1306 (2008).

24. R Core Team. R: A Language and Environment for Statistical Computing. R Foundation for Statistical Computing, Vienna, Austria. https://www.R-project.org/ (2018). Accessed 24 Apr 2019.

25. Albertsen, C. M., Whoriskey, K., Yurkowski, D., Nielsen, A. \& Flemming, J. M. Fast fitting of non-Gaussian state-space models to animal movement data via template model builder. Ecology 96, 2598-2604 (2015).

26. Albertsen, C. M. argosTrack: Fit Movement Models to Argos Data for Marine Animals. $R$ package version 1.2.2. https://doi. org/10.5281/zenodo.1420418, https://github.com/calbertsen/argosTrack/tree/v1.2.2 (2018). Accessed 20 Aug 2019.

27. Bryant, E. 2D Location Accuracy Statistics for Fastloc ${ }^{\circledR}$ Cores Running Firmware Versions 2.2 \& 2.3. (2007).

28. Tomkiewicz, S. M., Fuller, M. R., Kie, J. G. \& Bates, K. K. Global positioning system and associated technologies in animal behaviour and ecological research. Philos. Trans. R. Soc. B Biol. Sci. 365, 2163-2176 (2010).

29. Pohlert, T. Trend: non-parametric trend tests and change-point detection. R package version, 1(0). https://cran.r-project.org/web/ packages/trend/trend.pdf (2018). Accessed 10 Aug 2019.

30. Heide-Jørgensen, M., Richard, P., Dietz, R. \& Laidre, K. A metapopulation model for Canadian and West Greenland narwhals. Anim. Conserv. 16, 331-343 (2012).

31. Komsta, L. \& Komsta, M. L. Package 'mblm'. https://cran.pau.edu.tr/web/packages/mblm/mblm.pdf (2013). Accessed 10 Aug 2019.

32. Chambault, P. et al. Sea surface temperature predicts the movements of an Arctic cetacean: the bowhead whale. Sci. Rep. 8, 9658 (2018).

33. Heide-Jørgensen, L. M. P. \& Nielsen, T. G. Role of the bowhead whale as a predator in West Greenland. Mar. Ecol. Prog. Ser. 346, 285-297 (2008).

34. Laidre, K. L. \& Heide-Jørgensen, M. P. Winter feeding intensity of narwhals (Monodon monoceros). Mar. Mammal. Sci. 21, 45-57 (2005).

35. Forster, C. Spatial Patterns, Environmental Correlates, and Potential Seasonal Migration Triangle of Arctic cod (Boreogadus saida) Distribution in the Chukchi and Beaufort seas (2019).

36. Laurel, B. J., Copeman, L. A., Spencer, M. \& Iseri, P. Temperature-dependent growth as a function of size and age in juvenile Arctic cod (Boreogadus saida). ICES J. Mar. Sci. 74, 1614-1621 (2017).

37. Laidre, K. L. et al. Seasonal narwhal habitat associations in the high Arctic. Mar. Biol. 145, 821-831 (2004).

38. Schmidt-Nielsen, K. Animal Physiology: Adaptation and Environment (Cambridge University Press, Cambridge, 1997).

39. Castellini, M. Thermoregulation. in Encyclopedia of Marine Mammals (eds Perrin, W. F. et al.) 1166-1171 (Academic Press, Cambridge, 2009).

40. Kanwisher, J. W. \& Ridgway, S. H. The physiological ecology of Whales and Porpoises. Sci. Am. 248, 110-121 (1983).

41. Williams, T. M., Noren, S. R. \& Glenn, M. Extreme physiological adaptations as predictors of climate-change sensitivity in the narwhal Monodon monoceros. Mar. Mammal Sci. 27, 334-349 (2010).

42. McLaughlin, F. A., Carmack, E. C., Ingram, R. G., Williams, W. \& Michel, C. Oceanography of the Northwest Passage. in The Sea 26 (ed. Banville, J.) 1211-1242 (President and Fellows of Harvard College, Boston, 2004).

43. Kern, S., Kaleschke, L. \& Spreen, G. Climatology of the Nordic (Irminger, Greenland, Barents, Kara and White/Pechora) Seas ice cover based on $85 \mathrm{GHz}$ satellite microwave radiometry: 1992-2008. Tellus Dyn. Meteorol. Oceanogr. 62, 411-434 (2010).

44. Hansen, R. G., Borchers, D. L. \& Heide-Jørgensen, M. P. Abundance of narwhals summering in East Greenland and narwhals wintering in the North Water and Northeast Water polynyas. J. Mammal. 91, 1135-1151 (2019).

45. Riewe, R. Inuit land in the high Canadian Arctic. in Report Inuit land use and occupancy project 173-184 (1976).

46. Riewe, R. The utilisation of wildlife in the Jones Sound region by Grise Fjord Inuit. in Truelove Lowland, Devon Island, Canada: A high Arctic Ecosystem 623-644 (1977).

47. Riewe, R. Nunavut atlas. Canadian Circumpolar Institute and Tungavik Federation of Nunavut (1992).

48. Watt, C. A., Doniol-Valcroze, T., Witting, L., Hobbs, R. C., Hansen, R. G., Lee, D. S., ... \& Heide-Jorgensen, M. P. (2019). Hunt allocation modeling for migrating animals: The case of Baffin Bay narwhal, Monodon monoceros. Mar. Fish. Rev, 81(3-4), 125-136.

49. Witting, L., Doniol-Valcroze, T., Hobbs, R. C., Ditlevsen, S. \& Heide-Jørgensen, M. Meta-population modelling of narwhals, Monodon monoceros, in East Canada and West Greenland. Mar. Fish. Rev. 81, 116-138 (2019) (in press).

50. NAMMCO. Report of the Ad hoc Working Group on Narwhal in East Greenland. https://nammco.no/wp-content/uploa ds/2018/05/report-global-review-of-monodontids-nammco-2018_after-erratum-060518_with-appendices_2.pdf (2019). Accessed 10 Aug 2019.

51. Kvadsheim, P. H. \& Folkow, L. P. Blubber and flipper heat transfer in harp seals. Acta Physiol. Scand. 161, 385-395 (1997).

52. Kvadsheim, P. H., Gotaas, A. R. L., Folkow, L. P. \& Blix, A. S. An Experimental validation of heat loss models for marine mammals. J. Theor. Biol. 184, 15-23 (1997).

53. Scholander, P. Evolution of climatic adaptation in homeotherms. Evolution 9, 15-26 (1955).

54. Noren, D. P., Williams, T. M., Berry, P. \& Butler, E. Thermoregulation during swimming and diving in bottlenose dolphins Tursiops truncatus. J. Comp. Physiol. B 169, 93-99 (1999).

55. Innes, S. et al. Surveys of belugas and narwhals in the Canadian High Arctic in 1996. NAMMCO Sci. Publ. 4, 169-190 (2002).

56. Richard, P. et al. Baffin Bay Narwhal population distribution and numbers: aerial surveys in the Canadian high Arctic, 2002-04. Arctic 63, 85-99 (2010).

57. Asselin, N. C. \& Richard, P. Results of narwhal (Monodon monoceros) aerial surveys in Admiralty Inlet (2011).

58. Hansen, R. et al. Abundance of narwhals in Melville Bay in 2012 and 2014. (2015). 
59. Hansen, R. \& Heide-Jørgensen, M. P. Re-calculations of abundance of narwhals to three management units in East Greenland (2019).

\section{Acknowledgements}

We thank the hunters in Canada and Greenland for their assistance in catching and instrumenting the whales. This study was funded by the Commission for Scientific Research in Greenland, the Danish Cooperation for the Environment in the Arctic (DANCEA), the Carlsberg Foundation and the Greenland Institute of Natural Resources, as well as a grant from the Office of Naval Research (to TMW). The study is also part of the Northeast Greenland Environmental Study Program that is a collaboration between DCE (Danish Centre for Environment and Energy) at Aarhus University, the Greenland Institute of Natural Resources, and the Environmental Agency for Mineral Resource Activities of the Government of Greenland. Oil companies operating in Greenland are obliged to contribute to knowledge regarding environmental matters. The Strategic Environmental Impact Assessment and the background study program is funded under these commitments administered by the Mineral License and Safety Authority and the Environmental Agency for Mineral Resource Activities.

\section{Author contributions}

P.C. conducted the data analysis and wrote the manuscript. M.P.H.J. designed the experiment, collected the data, supervised the analysis and contributed to the manuscript. O.M.T., E.G., M.P.H.J. and R.G.H. assisted with organizing the data and analysis and interpretation of the results. K..L, P.R., and R.D. contributed to the data. P.C., O.M.T., E.G., R.G.H., S.B.B., T.M.W., R.D., C.M.A., K.L., N.H.N., P.R., M.H.S.S., H.C.S. and M.P.H.J. shared the responsibility for contributing to the final version of the manuscript.

\section{Competing interests}

The authors declare no competing interests.

\section{Additional information}

Supplementary information is available for this paper at https://doi.org/10.1038/s41598-020-75658-6.

Correspondence and requests for materials should be addressed to P.C.

Reprints and permissions information is available at www.nature.com/reprints.

Publisher's note Springer Nature remains neutral with regard to jurisdictional claims in published maps and institutional affiliations.

(c) (i) Open Access This article is licensed under a Creative Commons Attribution 4.0 International License, which permits use, sharing, adaptation, distribution and reproduction in any medium or format, as long as you give appropriate credit to the original author(s) and the source, provide a link to the Creative Commons licence, and indicate if changes were made. The images or other third party material in this article are included in the article's Creative Commons licence, unless indicated otherwise in a credit line to the material. If material is not included in the article's Creative Commons licence and your intended use is not permitted by statutory regulation or exceeds the permitted use, you will need to obtain permission directly from the copyright holder. To view a copy of this licence, visit http://creativecommons.org/licenses/by/4.0/.

(C) The Author(s) 2020 